\title{
Influence of Mortar Incorporating Silica Based Waste Material on the Formation of C-S-H and Mechanical Strength Properties
}

\author{
Nafisa Tamanna ${ }^{1, ~ a ~}$, Norsuzailina Mohamed Sutan ${ }^{1, \mathrm{~b}}$, Ibrahim Yakub ${ }^{2, \mathrm{c}}$, \\ Delsye Teo Ching Lee ${ }^{1, d}$, Ezzaq Farhan Ahmad ${ }^{1, e}$
}

${ }^{1}$ Department of Civil Engineering, Faculty of Engineering, Universiti Malaysia Sarawak (UNIMAS), 94300 Kota Samarahan, Sarawak, Malaysia

${ }^{2}$ Department of Chemical Engineering \& Energy Sustainability, Faculty of Engineering, University Malaysia Sarawak, 94300, Kota Samarahan, Sarawak, Malaysia

a nafisatamanna@yahoo.com, ${ }^{b}$ msnorsuzailina@feng.unimas.my, ${ }^{c}$ yibrahim@feng.unimas.my, dtdelsye@feng.unimas.my, ${ }^{\mathrm{e}}$ fezzaq@yahoo.com

\section{Keywords: Cement replacement, Compressive Strength, Calcium Silicate Hydrate (C-S-H), Glass} powder, Pozzolan

\begin{abstract}
Recent studies have been carried out to utilize waste glass in construction as partial cement replacement. This paper investigates the formation of Calcium Silicate Hydrate $(\mathrm{C}-\mathrm{S}-\mathrm{H})$ and strength characteristics of mortar in which cement is partially replaced with glass powder by replacement level of $10 \%, 20 \%$ and $30 \%$. Mortar cubes containing varying particle sizes in the ranges of $150-75 \mu \mathrm{m}, 63-38 \mu \mathrm{m}$ and lower than $38 \mu \mathrm{m}$ and in a water to cement ratio of 0.45 and 0.40 have been prepared. Replacement by $10 \%$ cement with glass powder reveals high compressive strength and produces more C-S-H at 28 days than other levels of replacement.
\end{abstract}

\section{Introduction}

Glass is one of the most indispensable materials used in a wide variety of applications in daily life. The amount of waste glass has increased with the increased use of glass in day to day life that not only accumulate on the landfills but also contribute to the environmental problems in the present time due to low rate of recycling [1]. Recently, waste glass has introduced as cement replacement in concrete production [2-3]. The feasibility of waste glass as cement replacement depends on its microstructure and mechanical strength properties. Waste glass can be used to replace cement but it must show either binding properties or pozzolanic properties [4-7]. Pozzolan is defined as a siliceous material which, in itself, possesses little or no cementing property but which will, in finely divided form and in the presence of moisture react chemically with calcium hydroxide at ordinary temperatures to form compounds possessing cementitious properties [8]. Being amorphous and containing relatively large quantities of silicon and calcium, glass is in theory pozzolanic or even cementitious in nature [9]. The glass might satisfy the basic requirements for a pozzolan if it is ground enough to passify the alkali silica reaction and to activate the pozzolanic behavior. This paper deals with the strength characteristics of mortar containing different sizes of glass powder with different water to cement ratio and an eventual focus on the formation of hydration compounds Calcium Silicate Hydrate $(\mathrm{CSH})$ and Calcium Hydroxide $(\mathrm{CH})$ which indicates thepozzolanic properties of the sample. Cement is replaced by glass powder varying from 10 to 30 percent by weight.

\section{Material and Methods}

Ordinary Portland Cement (OPC) ASTM Type 1 which is manufactured by Cahaya Mata Sarawak Cement Sdn. Bhd (CMS) was used throughout the research, and it confirmed to the requirements specified by the Malaysian Standard MS 522: Part 1: 1989 Specifications for OPC. Waste Glass used in this study was soda-lime clear glass that grinded in the grinding machine (Los Angeles 